\title{
Review
}

\section{Microparticles: new light shed on the understanding of venous thromboembolism}

\author{
Lin $\mathrm{ZHOU}^{1, \#}$, Xiao-long $\mathrm{Q}^{2, \text { \# }}$, Ming-xin $\mathrm{XU}^{2, ~ \#}, \mathrm{Yu} \mathrm{MAO}{ }^{1}$, Ming-lin $\mathrm{LIU}^{3}$, Hao-ming SONG ${ }^{1, *}$ \\ ${ }^{1}$ Division of Cardiology, Tongji Hospital, Tongji University School of Medicine, Shanghai 200065, China; ${ }^{2}$ Division of Gastroenterology \\ and Hepatology, Tongji Hospital, Tongji University School of Medicine, Shanghai 200065, China; ${ }^{3}$ Section of Endocrinology, Diabetes \\ and Metabolism, Temple University School of Medicine, Philadelphia 19140, PA, USA
}

\begin{abstract}
Microparticles are small membrane fragments shed primarily from blood and endothelial cells during either activation or apoptosis. There is mounting evidence suggesting that microparticles perform a large array of biological functions and contribute to various diseases. Of these disease processes, a significant link has been established between microparticles and venous thromboembolism. Advances in research on the role of microparticles in thrombosis have yielded crucial insights into possible mechanisms, diagnoses and therapeutic targets of venous thromboembolism. In this review, we discuss the definition and properties of microparticles and venous thromboembolism, provide a synopsis of the evidence detailing the contributions of microparticles to venous thromboembolism, and propose potential mechanisms, by which venous thromboembolism occurs. Moreover, we illustrate a possible role of microparticles in cancer-related venous thromboembolism.
\end{abstract}

Keywords: microparticle; blood cell; endothelial cell; venous thromboembolism; intercellular communication; inflammation; cancer

Acta Pharmacologica Sinica (2014) 35: 1103-1110; doi: 10.1038/aps.2014.73; published online 25 Aug 2014

\section{Introduction}

Significant progress has been made recently in our understanding of microparticles (MPs). MPs (also called microvesicles) are small $(0.1-1 \mu \mathrm{m})$ membrane fragments shed primarily from blood and endothelial cells (ECs) during either activation or apoptosis. They are detected and characterized on the basis of their heterogeneous compositions, which reflect their cellular origins ${ }^{[1]}$.

Despite circulating in both blood and biological fluids in healthy individuals, MPs have been implicated in a wide spectrum of diseases, including cardiovascular disease ${ }^{[2-4]}$, diabetes ${ }^{[5]}$, inflammatory states ${ }^{[6,7]}$, sepsis ${ }^{[8]}$, antiphospholipid antibody syndrome ${ }^{[9,10]}$, thrombotic thrombocytopenic purpura $^{[11]}$ and cancer ${ }^{[12]}$. Many of these conditions are characterized by a hypercoagulable state, which may lead to thrombosis. Additionally, an important link between MPs and venous thromboembolism (VTE) has been established via the collection of large amounts of new evidence, which may shed light on novel interpretations of how VTE occurs and represent possible therapeutic approaches for treating the phenomenon.

\footnotetext{
\# These authors contributed equally to this article.

* To whom correspondence should be addressed.

E-mail haomingsongtj@126.com

Received 2014-01-28 Accepted 2014-06-05
}

This review discusses relevant studies and highlights the contributions of MPs to VTE, as well as the potential role played by MPs in cancer.

\section{Definition and properties}

MP formation, composition, and function

A wide variety of normal cells (blood cells and ECs) generate MPs, as do malignant cells. Both chemical (eg, cytokines, thrombin, cytotoxic chemotherapy ${ }^{[13]}$, cholesterol enrichment ${ }^{[14]}$ and tobacco smoke exposure $\left.{ }^{[15]}\right)$ and physical stimulation (eg, shear stress, hypoxia and stimuli ${ }^{[16-18]}$ ) trigger MP release. Additionally, MPs participate in cell apoptosis.

Cell activation leads to elevated levels of intracellular $\mathrm{Ca}^{2+}$, resulting in the disruption of membrane asymmetry and in increased exposure of phosphatidylserine (PS), which resides in the inner membrane, to the cell surface, as well as membrane blebbing and subsequent MP shedding ${ }^{[19]}$. Although calcium entry and the following activities play a putative role in MP formation, the exact mechanisms that govern MP formation remain unclear. Previous studies have shown that mitogen-activated protein kinases (MAPKs) are involved in the process of MP formation through the investigation of MPs produced by human macrophages when exposed to tobacco smoke ${ }^{[20]}$. Additional studies are needed to better outline mechanisms of MP formation and to investigate whether there 
are differences in the mechanisms underlying MP formation, depending on whether this process is associated with activation or apoptosis.

As sealed membrane vesicles, MPs not only bear antigens indicative of their cellular origin but also retain biological molecules. Considered to be key features of a ubiquitous and highly organized system of cell communication and intercellular material transport ${ }^{[21-24]}$, MPs may induce cell signaling $^{[25]}$ and regulate many pathophysiological processes ${ }^{[26]}$ by harboring inflammatory components (LpA and cytokines), growth factors (TGF beta and VEGF) and proteases (uPA and $\mathrm{MMP})^{[25,27]}$, in addition to altering the activities of tissue factor $(\mathrm{TF})^{[28]}$ and PS.

\section{MP detection and measurement}

Currently, flow cytometry is the most common method of quantifying MPs. MPs may also be detected using antibody capture assays, such as enzyme-linked immunosorbent assay ${ }^{[29]}$, or modified capture protocols that detect functional properties of MPs. Results of MP functional assays and the number of MPs identified by flow cytometry from the same sample are often uncorrelated. A pitfall of flow cytometry is that it has limited forward scatter sensitivity; therefore, standard flow cytometers measure only a small portion of the MP population. Fortunately, recent technological improvements resulting in the advent of high sensitivity flow cytometry have made it possible to measure small-size MPs, which represents a new opportunity to utilize flow cytometry for MP measurement ${ }^{[30]}$. We believe that flow cytometry will remain a mainstream approach for testing MP levels in the near future; however, a standardized testing protocol must be established. To accomplish this, research regarding sources of variability within the assay is necessary. Additionally, new techniques, such as laser-induced nanotracking ${ }^{[31]}$, atomic force micros$\operatorname{copy}^{[32]}$, and dynamic light scattering, have been developed. These advances represent exciting possibilities for MP measurement.

Information about a series of recent studies ${ }^{[33-38]}$ investigating MPs in patients with VTE is included in this article (Table 1 and 2). Most of the studies demonstrated an increase in different types of MPs, but some did not, resulting in an inconsistency among the results of these investigations. There may be several reasons for these discrepancies. One reason may be different times of blood sampling. According to Table 1 and 2, blood samples were collected in the setting of acute events in the studies by Chirinos et al, Ye et al and Bai et al ${ }^{[34,36-38]}$. However, Bucciarelli et $a l^{[35]}$ collected blood samples after the first episode of VTE ( $<5$ years) and long ( $>3$ months) after any possible trigger events, such as surgery or pregnancy, which may affect MP levels. Ay et $a l^{[33]}$ studied patients suffering from recurrent VTE and collected their blood at least 3 months after each patient's most recent VTE event. Studies that collected blood samples in the setting of an acute event demonstrated elevated MP levels, which are associated with VTE, but the study by Ay et $a l^{[33]}$, which collected blood long after each acute episode, failed to demonstrate these findings. However, the study by Bucciarelli et al ${ }^{[35]}$ revealed that an increased relative risk of VTE was still observed in association with high MP levels when patients were tested soon after their VTE, although this information was excluded from their analysis of VTE risk. Therefore, the effects of acute disease processes on MP formation remain unclear. Another reason for the inconsistencies may be the different methods utilized in each study. As previously mentioned, the studies by Bucciarelli et al ${ }^{[35]}$ and Ay et $a l^{[33]}$ presented different outcomes following the investigation of blood samples collected at times long after an acute event. Flow cytometry was used to evaluate MP levels in the former ${ }^{[35]}$, whereas functional assays were utilized for the latter project ${ }^{[33]}$. Unlike flow cytometry, which provides details regarding size, number and origin of MPs, functional assays provide information on MP activity. Therefore, we speculated that the utilization of different analysis methods may have played a critical role in the final results of each study. A third reason for the discrepant results may be differences in the markers used to identify MPs because several types were used to identify MPs. In the three studies in question ${ }^{[34,37,38] \text {, }}$ there were three types of markers used to assess the MPs (CD31+, CD42b+, CD41a+, and glycoprotein Ib+), which may explain the conflicting results of these studies. The discordant findings caused by the utilization of different techniques

Table 1. Studies measuring microparticles in non-acute conditions in patients with venous thromboembolism.

\begin{tabular}{|c|c|c|c|c|c|c|c|}
\hline Study & Subjects & $\begin{array}{c}\text { Study/control } \\
\text { Number }\end{array}$ & Time of blood sampling & Method & $\begin{array}{c}\text { MPs } \\
\text { detected }\end{array}$ & Specific marker & Results \\
\hline Ay et $a l^{[33]}$ & $\begin{array}{l}\text { Patients with } \\
\text { recurrent VTE }\end{array}$ & $116 / 129$ & $\begin{array}{l}>3 \text { months after the most } \\
\text { recent event of VTE }\end{array}$ & Functional assay & CPMPs & Annexin V+ & $\uparrow$ \\
\hline Bucciarelli et al ${ }^{[35]}$ & $\begin{array}{l}\text { Patients after a } \\
\text { first episode of VTE }\end{array}$ & $186 / 418$ & $\begin{array}{l}\text { After the first episode of VTE }(<5 \\
\text { years) and far ( }>3 \text { months) from } \\
\text { triggering events }\end{array}$ & Flow cytometry & $\begin{array}{l}\text { Total MPs } \\
\text { PMP } \\
\text { MPTF }\end{array}$ & $\begin{array}{l}\text { Annexin V+ } \\
\text { Annexin V+, CD41+ } \\
\text { Annexin V+, CD142+ }\end{array}$ & $\begin{array}{l}\uparrow \\
\uparrow \\
\uparrow\end{array}$ \\
\hline
\end{tabular}

$\uparrow$ Means a significant increase of MPs in patients with VTE compared with healthy controls; - means no significant difference found between patients with VTE and healthy controls.

CPMPs, circulating procoagulant microparticles; MP, microparticle; MPTF, tissue factor-bearing microparticle; PMP, platelet microparticle; VTE, venous thromboembolism. 
Table 2. Studies measuring microparticles in acute conditions in patients with venous thromboembolism.

\begin{tabular}{|c|c|c|c|c|c|c|c|}
\hline Study & Subjects & $\begin{array}{l}\text { Study/ } \\
\text { control } \\
\text { Number }\end{array}$ & $\begin{array}{l}\text { Time of blood } \\
\text { sampling }\end{array}$ & Method & MPs detected & Specific marker & Results \\
\hline Bai et al $l^{[34]}$ & $\begin{array}{l}\text { Patients with } \\
\text { acute PE }\end{array}$ & $45 / 45$ & $\begin{array}{l}\text { In acute condition } \\
\text { of VTE }\end{array}$ & $\begin{array}{l}\text { Functional } \\
\text { assay }\end{array}$ & $\begin{array}{l}\text { CPMP } \\
\text { PMP } \\
\text { EMP }\end{array}$ & $\begin{array}{l}\text { Annexin V+ } \\
\text { Glycoprotein Ib+ } \\
\text { CD31+ }\end{array}$ & $\begin{array}{l}\uparrow \\
\uparrow \\
-\end{array}$ \\
\hline Campello et al ${ }^{[36]}$ & $\begin{array}{l}\text { Patients with a } \\
\text { first episode of } \\
\text { unproked VTE }\end{array}$ & $30 / 90$ & $\begin{array}{l}\text { In acute condition } \\
\text { of VTE }\end{array}$ & $\begin{array}{l}\text { Flow } \\
\text { cytometry }\end{array}$ & $\begin{array}{l}\text { EMP } \\
\text { PMP } \\
\text { MPTF }\end{array}$ & $\begin{array}{l}\text { Annexin } \mathrm{V}+, \text { CD146 } \\
\text { Annexin } \mathrm{V}+, \text { CD61 } \\
\text { Annexin } \mathrm{V}+, \text { mAb anti-TF }\end{array}$ & $\begin{array}{l}\uparrow \\
\uparrow \\
\uparrow\end{array}$ \\
\hline Chirinos et al ${ }^{[37]}$ & $\begin{array}{l}\text { Patients with } \\
\text { acute VTE }\end{array}$ & $25 / 25$ & $\begin{array}{l}\text { In acute condition } \\
\text { of VTE }\end{array}$ & $\begin{array}{l}\text { Flow } \\
\text { cytometry }\end{array}$ & $\begin{array}{l}\text { EMP } \\
\text { PMP } \\
\text { Platelet activation } \\
\text { Leukocyte activation } \\
\text { EMP-monocyte conjugates } \\
\text { Platelet-leukocyte conjugates }\end{array}$ & $\begin{array}{l}\text { CD31+, CD42b-; CD62E } \\
\text { CD31+, CD42b+ } \\
\text { CD62P } \\
\text { CD11b } \\
\text { CD45+, CD62E } \\
\text { CD45+, CD41+ }\end{array}$ & $\begin{array}{l}\uparrow \\
- \\
\uparrow \\
\uparrow \\
\uparrow \\
\uparrow\end{array}$ \\
\hline Ye et $a 1^{\$[38]}$ & $\begin{array}{l}\text { Patients with } \\
\text { acute recurrent } \\
\text { VTE }\end{array}$ & $25 / 25$ & $\begin{array}{l}\text { In acute condition } \\
\text { of VTE }\end{array}$ & $\begin{array}{l}\text { Flow } \\
\text { cytometry }\end{array}$ & $\begin{array}{l}\text { Total MP/MPTF } \\
\text { Monocyte-derived MP/MPTF } \\
\text { PMP/MPTF from platelets } \\
\text { EMP/MPTF from endothelial cells } \\
\text { Erythrocyte-derived MP/MPTF }\end{array}$ & $\begin{array}{l}\text { Annexin V+/Annexin V+, 4507CJ+ } \\
\text { CD14+/CD14+, 4507CJ+ } \\
\text { CD41a+/CD41a+, 4507CJ+ } \\
\text { CD144+/CD144+, 4507CJ+ } \\
\text { CD235a+/CD235a+, 4507CJ+ }\end{array}$ & $\begin{array}{l}\uparrow / \uparrow \\
\uparrow / \uparrow \\
-/ \uparrow \\
\uparrow / \uparrow \\
-/-\end{array}$ \\
\hline
\end{tabular}

$\uparrow$ means a significant increase of MPs in patients with VTE compared with healthy controls; - means no significant difference found between patients with VTE and healthy controls.

${ }^{\$}$ Annexin V+/Annexin V+, 4507CJ+ means Annexin V+ for total MP, Annexin V+, 4507CJ+ for total MPTF, respectively. So do the rest expression in the study of Ye et al.

CPMP, circulating procoagulant microparticle; EMP, endothelial microparticle; MP, microparticle; MPTF, tissue factor-bearing microparticle; PE, pulmonary embolism; PMP, platelet microparticle; VTE, venous thromboembolism.

and different methodological approaches have blurred our understanding of MP activities and increased our craving for standardized assays capable of generating results with a high degree of reproducibility.

\section{Contribution of MPs to VTE}

VTE is a multifactorial disease that includes deep venous thrombosis (DVT) and pulmonary embolism (PE). Increasing evidence points to elevated levels of different phenotypes of MPs in patients with VTE, suggesting that MPs play an important role in the pathophysiology of $\mathrm{VTE}^{[34-38]}$. It is noteworthy that inflammation and thrombosis are coupled via common activation pathways and feedback regulation systems because this establishes a relationship between VTE and inflammation. The functional interplay among ECs, platelets, inflammatory cells and MPs deduced by studying those cells may play an indispensable role in VTE. We have elucidated the effects of MPs on thrombogenesis in three ways based on previous studies: the expression of TF and exposure of PS, MP-induced intercellular communication, and MP involvement in crosstalk between inflammation and VTE. Further research is required, however, to determine whether circulating concentrations of MPs are sufficient to facilitate thrombus formation and mediate inflammation.

\section{Procoagulant properties of MP: the expression of TF and the} exposure of PS

Circulating monocytes, MPs, and activated endothelium produce a procoagulant protein, $\mathrm{TF}$, under pathological conditions $^{[39,40]}$. These intravascular sources of TF may trigger the formation of venous clots via the extrinsic pathway of the blood coagulation cascade. Although activated monocytes and tumor cells are the primary sources of TF-positive MPs in the circulation ${ }^{[41]}$, TF has been identified on leukocyte MPs, endothelial microparticles (EMPs) and platelet microparticles (PMPs $^{[9,11,42-46]}$. Additionally, it is interesting to note that the density of active TF on microvesicles (MVs) was higher than the protein's density on their parental cells ${ }^{[47]}$, which supports the hypothesis that MP formation is not entirely a random process and that MPs are effective products made in response to a changing environment.

The idea that TF is a potent trigger of VTE is promising, although accurate mechanisms detailing its involvement in the coagulation system have not been clearly elucidated. This important role has been consigned to TF not only as a result of its over-expression in the setting of thrombotic processes but also because a genetic deficiency in TF in hematopoietic cells and myeloid cells dramatically reduces the incidence of venous thrombosis, which indicates that TF expression by leu- 
kocytes and leukocyte derived MVs initiate thrombosis; this has been suggested by recent studies using a mouse inferior vena cava stenosis model ${ }^{[48]}$. TF-positive MPs may therefore serve as a critical source of TF and play an active role in the initiation of VTE.

The exposure of PS is another trait of MP formation. The anionic PS serves as a catalytic surface for the assembly of the prothrombinase complex ${ }^{[49]}$. Moreover, phospholipids on the surface of MPs derived from platelets and ECs provide a number of binding sites for factors Va, VIII, IXa, and IIa ${ }^{[49-52]}$, allowing for concentrations necessary to achieve optimal thrombin generation and efficient hemostasis ${ }^{[53]}$. Therefore, PS amplifies the procoagulant activity of TF and contributes to the propagation of the coagulation cascade.

\section{MP-induced intercellular communication}

Studies in several settings ${ }^{[14,15,45]}$ have demonstrated that only a minority of microvesicles are TF-positive. Recent studies suggest that microvesicles are significant mediators of intercellular communication under physiologic and pathologic conditions $^{[54-56]}$. Our previous project indicated that MPs from cholesterol-loaded human cells function as novel carriers of damage-associated molecular patterns ${ }^{[57]}$. Therefore, microvesicles may arise from and mediate novel physiologic and pathologic effects independent of coagulation. We propose that MPs may play this role by acting as mediators of endothelial dysfunction and serving as shuttles promoting cellular cross-talk ${ }^{[58]}$. In this study, we focused on MP-induced intercellular communication and the possible role of this mediation in the underlying processes of VTE formation.

\section{EMP-induced intercellular communication}

The most common site of thrombus formation in humans is the valve pocket sinus, which results from turbulent flow and hypoxia ${ }^{[59]}$. The endothelium at this location may be activated by either hypoxia or inflammatory mediators and subsequently expresses the adhesion proteins P-selectin, E-selectin, and von Willebrand factor (vWF), which capture leukocytes, platelets, and MPs ${ }^{[60,61]}$. Additionally, activated ECs release EMPs. In addition to the aforementioned procoagulant properties of MPs, which are related to TF expression and PS exposure, EMPs may lead directly to the development of endothelial dysfunction. It has been demonstrated that patients with VTE show marked elevations in EMP identified by CD31+/ CD42b-(EMP $\left.{ }_{31}\right)$ (2193 vs 383 counts $\left./ \mu L ; P=0.003\right)$, E-selectin $\left(\mathrm{EMP}_{62 \mathrm{E}}\right)(368$ vs 223 counts $/ \mu \mathrm{L} ; P=0.001)$, and EMP-monocyte conjugates $(3.3 \% \text { vs } 2.5 \% ; P=0.002)^{[37]}$. These findings support those of prior studies suggesting that the release of EMP and its subsequent binding to monocytes are key events in thrombogenesis ${ }^{[62,63]}$. Additionally, in vitro experiments have demonstrated that EMPs promote and stabilize platelet aggregates by expressing ultralarge $\mathrm{vWF}^{[64]}$ and that oxidized phospholipids in EMPs exposed to oxidative stress may be particularly active in mediating both monocyte adherence to ECs and the activation of neutrophils ${ }^{[65,66]}$.
Intercellular communication associated with MPs derived from leukocytes

Marked leukocyte activation (13.9 vs $7.7 \mathrm{U}$ for CD11b; $P=0.004)$ in the setting of VTE was observed in a recent study ${ }^{[37]}$. MPs derived from leukocytes express P-selectin glycoprotein ligand-1 (PSGL-1), which is inherited from their parental cells and interacts with a key endothelial cell receptor, P-selectin. Reduced thrombosis was demonstrated via the inhibition and deficiency of P-selectin ${ }^{[67-69]}$, which indicate that the interaction between PSGL-1 and P-selectin, specifically the binding of leukocyte-derived MPs to the activated endothelium, is involved in thrombogenesis. These studies also suggest that blocking the binding of leukocytes and MPs to activated EC may provide a novel strategy for preventing VTE. Moreover, it has been suggested that MPs shed by leukocytes stimulate cytokine release and the induction of TFs in ECs by activating a signaling pathway involving the tyrosine phosphorylation of c-Jun $\mathrm{NH}_{2}$-terminal kinase-1, which may lead to increased proinflammatory and procoagulant activity in $\mathrm{ECs}^{[70]}$.

Leukocyte-derived MPs also contribute to the development of thrombi through the recruitment of platelets and the accumulation of TF. ECs and platelets express P-selectin. As demonstrated previously, monocytes and macrophages are primary sources of circulating TF via the shedding of TF-bearing MPs ${ }^{[41]}$. These MPs, which have PSGP-1 on their surface, participate in platelet thrombus formation not merely by binding to P-selectin on activated platelets ${ }^{[67]}$ but by fusing with these platelets via PSGL-1, transferring lipids and proteins, including $\mathrm{TF}$, into their plasma membranes ${ }^{[71]}$.

\section{PMP-induced intercellular communication}

There was a dramatic increase in platelet activation (35.2 vs 5.0 fluorescence intensity units for P-selectin; $P<0.0001)$ in the setting of VTE, which was found in the recent study by Chirinos et $a l^{[37]}$. Likewise, elevated PMPs were detected in patients with VTE in two other studies ${ }^{[34,35]}$, and a strong correlation was found between total MPs and PMPs $(\rho=0.99, P<0.0001)$ and between PMPs and TF-bearing MPs $(\rho=0.94, P<0.0001)$ in the study by Bucciarelli et $a l^{[35]}$. An increased amount of TFbearing MPs of platelet origin $(P=0.004)$ was found in patients with acute recurrent VTE, whereas no significant differences in total PMPs $(P=0.062)$ were found when these results were compared with similar studies in healthy subjects ${ }^{[38]}$. These findings indicate an association among PMPs and TF-bearing MPs of platelet origin and VTE. However, there is unfortunately no direct evidence corroborating the existence of PMPinduced intercellular communication in vivo. However, a series of in vitro studies have suggested these putative effects of PMP based on interactions with other cells. These studies demonstrated that MPs released by aggregating platelets may facilitate platelet activation and EC activation via the transcellular delivery of arachidonic acid or other mediators ${ }^{[72,73]}$. Moreover, PMP binds to and activates neutrophils in vitro ${ }^{[74]}$. Further in vivo studies are necessary to address the role of PMP in this process. 


\section{MP involvement in crosstalk between inflammation and VTE}

Inflammation and hemostasis share an interactive relationship because they are linked via common activation pathways and feedback regulation systems. Emerging evidence supports the idea that MPs may play a role in crosstalk between inflammation and thrombosis. As suggested in the recent study by Chirinos et $a l^{[37]}$, patients with VTE demonstrated dramatic elevations in their levels of MPs and conjugates between platelets and leukocytes (PLC) $(61.7 \%$ vs $39.6 \%$; $P=0.01)$. They also found that there was a strong correlation between PLC and the degree of leukocyte activation $(r=0.74 ; P<0.0001)$. Their results support the idea that the formation of PLC regulates leukocyte activation and participates in linking thrombosis to inflammation. This link may be related to the increased levels of MPs because EMPs, like PMPs, have been shown to function as vectors for many inflammatory mediators ${ }^{[73]}$. Additionally, leukocyte-derived MPs may precipitate increased proinflammatory and procoagulant activity by interacting with other cells by aforementioned means.

In summarizing the functions of MPs, we propose a mechanism for VTE according to the above points (Figure 1). ECs located at the valve pocket sinus may be activated by either hypoxia or inflammatory mediators. Activated ECs express the adhesion proteins, P-selectin, E-selectin, and vWF, which capture leukocytes, platelets and MPs, and release EMPs. Circulating leukocytes bind to ECs and EMPs via P-selectin and E-selectin, and platelets bind to ECs via vWF. These bindings activate leukocytes, inducing TF expression on leukocytes and triggering the shedding of TF-bearing MPs from leukocytes,

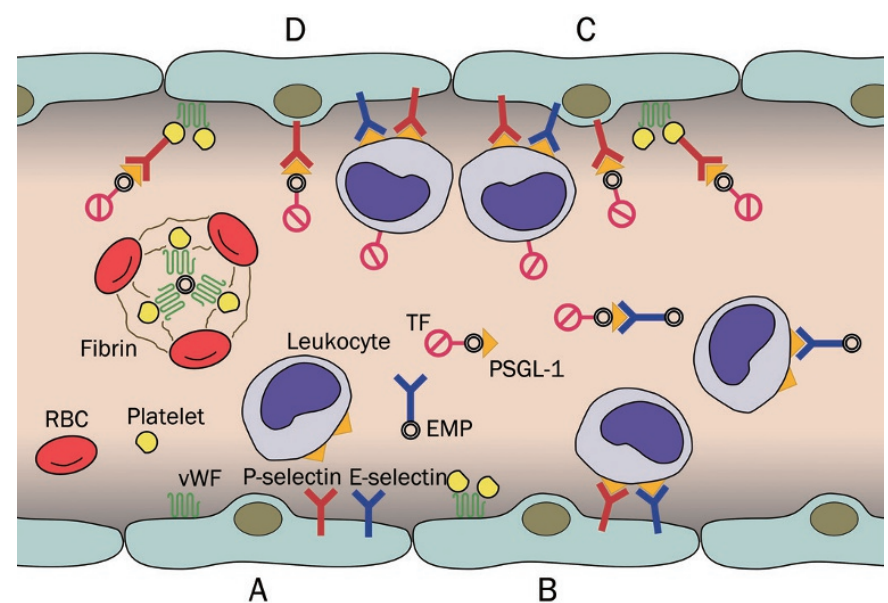

Figure 1. The role of microparticles in the mechanism of venous thromboembolism. (A) Activated endothelial cells express P-selectin, E-selectin, and VWF and release EMPs; (B) Leukocytes bind to endothelial cells and EMPs via P-selectin and E-selectin; platelets bind to endothelial cells via vWF; (C) These bindings activate leukocytes that induce TF expression and shedding of TF-bearing EMPs, which interact with endothelial cells and activated platelets; (D) The high concentration of TF and wide catalytic surface contribute to thrombosis; EMPs express VWF to stabilize platelet aggregation. EMPs, endothelial microparticles; PSGL-1, P-selectin glycoprotein ligand-1; TF, tissue factor; vWF, von Willebrand factor. which may interact with ECs and activated platelets. The high concentration of TF and the wide catalytic surface for the assembly of the prothrombinase enzyme complex trigger thrombus formation. Additionally, EMPs may express vWF to stabilize platelet aggregation (Figure 1).

\section{Contribution of MPs to cancer-related VTE}

There is a strong correlation between VTE and cancer regardless of cancer types and stages. Given the crucial role that MPs play in the process of VTE, the relationship between MPs and cancer has been the subject of recent studies and review articles, which have offered novel interpretations of the interaction among MPs, thrombosis and cancer ${ }^{[36,75-79]}$.

A study investigating endothelial cells, platelets, and TFpositive MPs in cancer patients with and without VTE demonstrated statistically significant elevations in TF-positive MP plasma levels $(1019 \pm 656 \mathrm{MPs} / \mu \mathrm{L})$ in cancer patients with VTE compared to cancer patients without VTE (755 \pm 391 MPs/ $\mu \mathrm{L}, P=0.002)^{[36]}$. Nevertheless, multivariate analysis failed to show a significant association between elevated TF-positive MPs and VTE in cancer patients ${ }^{[36]}$. Another study demonstrated that patients with different types of cancer who also developed VTE demonstrated higher numbers of circulating MPs and particularly higher activity levels of TF-bearing MPs than cancer patients without $\mathrm{VTE}^{[80]}$, a finding confirmed by three other studies that used flow cytometry, chromogenic assays, and prothrombinase assays ${ }^{[77-79]}$. Collectively, these studies have corroborated the existence of an association between thrombosis and TF-bearing MP expression in cancer. However, this causal relationship is questionable because the possibility of a reverse causal relationship (ie, thrombosis and other potential confounders result in increased MP formation) cannot be excluded in some instances.

Briefly, MPs are postulated to mediate several of the following aspects of cancer: the release of TF-bearing MPs derived from both cancer cells and host cells may lead specifically to a hypercoagulable state in cancer patients. MPs may contribute to malignancy propagation by promoting angiogenic processes, impairing both the immune response and cell engraftment, which may lead to an additional release of MPs. Additional studies are required to better clarify the relationships among MPs, cancer and VTE.

\section{Therapeutic potential of MPs}

We summarized several approaches by which therapeutic agents may counteract MPs prothrombotic actions and carcinogenesis based on past research. First, oncogene-directed treatments may have a profound impact on the morbidity and survival of oncologic patients by attenuating the prothrombotic effects of MPs in cancer ${ }^{[81]}$. Blocking MP-induced intercellular communication is another approach. P-selectin is a key endothelial cell receptor that captures circulating leukocytes and leukocyte-derived MPs expressing PSGL-1 ${ }^{[82]}$. Emerging studies have suggested that blocking the binding of leukocytes and MPs to activated endothelium via P-selectin inhibitors may represent a novel strategy for reducing the 
incidence of $\operatorname{VTE}^{[67-69,83-87]}$. Inducing angiogenesis regulation is a third approach. MPs are involved in many complex activities associated with angiogenesis. Although the mechanisms underlying these activities remain unclear, considerable effort has been expended to use MPs as therapeutic tools in diseases characterized by altered angiogenesis ${ }^{[88]}$. MPs may also be used as vectors for the delivery of chemotherapeutic drugs. Because MPs apparently exhibit homing ability, they may be useful "cargo" for the targeted delivery of therapeutic agents because they possess properties that enable them to localize to specific areas of target issues. Several studies have proposed a role for MPs in atherosclerosis, transplantation and cancer $^{[41,89-91]}$. Although recent progress has been made in the therapeutic use of MPs, further research is necessary because we cannot blindly apply them as therapeutic agents without a complete and clear understanding of the mechanisms underlying both MP formation and activity.

\section{Conclusions and perspectives}

MPs play a pivotal role in the initiation and propagation of VTE through the development of their own procoagulant properties, enhancing intercellular communication and promoting inflammation. Additionally, MPs are involved in crosstalk between cancer and VTE. MPs may not only exert deleterious effects in the setting of VTE but may also act as novel diagnostic markers and provide new and exciting opportunities and therapeutic approaches used to deter VTE and attenuate the prothrombotic effects of cancer. Nevertheless, further prospective clinical studies are required to investigate those effects, and standardized assays with high rates of reproducibility must be developed to avoid discrepancies caused by the various methods of MP measurement currently in use.

\section{Acknowledgements}

This study was supported by the Shanghai Municipal Bureau of Health Youth Scientific Research Projects (2009Y071) and the Shanghai Committee of Science and Technology Research Projects (11411951400).

\section{Abbreviations}

CPMP, circulating procoagulant microparticle; DVT, deep venous thrombosis; EC, endothelial cell; EMP, endothelial microparticle; EMPTF, tissue factor-bearing microparticle derived from endothelial cells; MAPK, mitogen-activated protein kinase; MMP, matrix metalloproteinase; MP, microparticle, MPTF, tissue factor-bearing microparticle; MV, microvesicle; PE, pulmonary embolism; PLC, conjugates between platelets and leukocytes; PMP, platelet microparticle; PMPTF, tissue factor-bearing microparticle derived from platelets; PS, phosphatidylserine; PSGL-1, P-selectin glycoprotein ligand-1; TF, tissue factor; vWF, von Willebrand factor; VTE, venous thromboembolism.

\section{References}

1 Ahn YS. Cell-derived microparticles: Miniature envoys with many faces. J Thromb Haemost 2005; 3: 884-7.

2 Bonderman D, Teml A, Jakowitsch J, Adlbrecht C, Gyöngyösi M, Sperker W, et al. Coronary no-reflow is caused by shedding of active tissue factor from dissected atherosclerotic plaque. Blood 2002; 99: 2794-800.

3 Leroyer AS, Isobe H, Lesèche G, Castier Y, Wassef M, Mallat Z, et al. Cellular origins and thrombogenic activity of microparticles isolated from human atherosclerotic plaques. J Am Coll Cardiol 2007; 49: 772-7.

4 Preston RA, Jy W, Jimenez JJ, Mauro LM, Horstman LL, Valle M, et al. Effects of severe hypertension on endothelial and platelet microparticles. Hypertension 2003; 41: 211-7.

5 Sabatier F, Darmon P, Hugel B, Combes V, Sanmarco M, Velut JG, et al. Type 1 and type 2 diabetic patients display different patterns of cellular microparticles. Diabetes 2002; 51: 2840-5.

6 Pamuk GE, Vural O, Turgut B, Demir M, Umit H, Tezel A. Increased circulating platelet-neutrophil, platelet-monocyte complexes, and platelet activation in patients with ulcerative colitis: a comparative study. Am J Hematol 2006; 81: 753-9.

7 Sheremata WA, Jy W, Horstman LL, Ahn YS, Alexander JS, Minagar A. Evidence of platelet activation in multiple sclerosis. J Neuroinflammation 2008; 5: 27.

8 Nieuwland R, Berckmans RJ, McGregor S, Böing AN, Romijn FP, Westendorp RG, et al. Cellular origin and procoagulant properties of microparticles in meningococcal sepsis. Blood 2000; 95: 930-5.

9 Combes V, Simon AC, Grau GE, Arnoux D, Camoin L, Sabatier F, et al. In vitro generation of endothelial microparticles and possible prothrombotic activity in patients with lupus anticoagulant. J Clin Invest 1999; 104: 93-102.

10 Dignat-George F, Camoin-Jau L, Sabatier F, Arnoux D, Anfosso F, Bardin N, et al. Endothelial microparticles: a potential contribution to the thrombotic complications of the antiphospholipid syndrome. Thromb Haemost 2004; 91: 667-73.

11 Jimenez JJ, Jy W, Mauro LM, Horstman LL, Ahn YS. Elevated endothelial microparticles in thrombotic thrombocytopenic purpura: findings from brain and renal microvascular cell culture and patients with active disease. Br J Haematol 2001; 112: 81-90.

12 Zwicker Jl. Tissue factor-bearing microparticles and cancer. Semin Thromb Hemost 2008; 34: 195-8.

13 Lynch SF, Ludlam CA. Plasma microparticles and vascular disorders. Br J Haematol 2007; 137: 36-48.

14 Liu ML, Reilly MP, Casasanto P, McKenzie SE, Williams KJ. Cholesterol enrichment of human monocyte/macrophages induces surface exposure of phosphatidylserine and the release of biologically-active tissue factor-positive microvesicles. Arterioscler Thromb Vasc Biol 2007; 27: 430-5.

15 Li M, Yu D, Williams KJ, Liu ML. Tobacco smoke induces the generation of procoagulant microvesicles from human monocytes/ macrophages. Arterioscler Thromb Vasc Biol 2010; 30: 1818-24.

16 Miyazaki Y, Nomura S, Miyake T, Kagawa H, Kitada C, Taniguchi H, et al. High shear stress can initiate both platelet aggregation and shedding of procoagulant containing microparticles. Blood 1996; 88: 3456-64.

17 VanWijk MJ, VanBavel E, Sturk A, Nieuwland R. Microparticles in cardiovascular diseases. Cardiovasc Res 2003; 59: 277-87.

18 Wiedmer T, Sims PJ. Participation of protein kinases in complement C5b-9-induced shedding of platelet plasma membrane vesicles. Blood 1991; 78: 2880-6.

19 Morel O, Jesel L, Freyssinet JM, Toti F. Cellular mechanisms underlying the formation of circulating microparticles. Arterioscler Thromb Vasc Biol 2011; 31: 15-26. 
20 Li CJ, Liu Y, Chen Y, Yu D, Williams KJ, Liu ML. Novel proteolytic microvesicles released from human macrophages after exposure to tobacco smoke. Am J Pathol 2013; 182: 1552-62.

21 Inal JM, Ansa-Addo EA, Stratton D, Kholia S, Antwi-Baffour SS, Jorfi $\mathrm{S}$, et al. Microvesicles in health and disease. Arch Immunol Ther Exp (Warsz) 2012; 60: 107-21.

22 Lee TH, D'Asti E, Magnus N, Al-Nedawi K, Meehan B, Rak J. Microvesicles as mediators of intercellular communication in cancer - the emerging science of cellular 'debris'. Semin Immunopathol 2011; 33: 455-67.

23 Morel O, Morel N, Jesel L, Freyssinet JM, Toti F. Microparticles: a critical component in the nexus between inflammation, immunity, and thrombosis. Semin Immunopathol 2011; 33: 469-86.

24 Tetta C, Bruno S, Fonsato V, Deregibus MC, Camussi G. The role of microvesicles in tissue repair. Organogenesis 2011; 7: 105-15.

25 Morel O, Toti F, Hugel B, Freyssinet JM. Cellular microparticles: a disseminated storage pool of bioactive vascular effectors. Curr Opin Hematol 2004; 11: 156-64.

26 Morel N, Morel O, Delabranche X, Jesel L, Sztark F, Dabadie P, et al. Microparticles during sepsis and trauma. A link between inflammation and thrombotic processes. Ann Fr Anesth Reanim 2006; 25: 955-66.

27 Morel O, Toti F, Hugel B, Bakouboula B, Camoin-Jau L, DignatGeorge $\mathrm{F}$, et al. Procoagulant microparticles: disrupting the vascular homeostasis equation? Arterioscler Thromb Vasc Biol 2006; 26 : 2594-604.

28 Bastida E, Ordinas A, Escolar G, Jamieson GA. Tissue factor in microvesicles shed from U87MG human glioblastoma cells induces coagulation, platelet aggregation, and thrombogenesis. Blood 1984; 64: $177-84$

29 Nomura S, Shouzu A, Taomoto K, Togane Y, Goto S, Ozaki Y, et al. Assessment of an ELISA kit for platelet-derived microparticles by joint research at many institutes in Japan. J Atheroscler Thromb 2009; 16: 878-87.

30 Robert S, Lacroix R, Poncelet P, Harhouri K, Bouriche T, Judicone C, et al. High-sensitivity flow cytometry provides access to standardized measurement of small-size microparticles - brief report. Arterioscler Thromb Vasc Biol 2012; 32: 1054-8.

31 Dragovic RA, Gardiner C, Brooks AS, Tannetta DS, Ferguson DJ, Hole P, et al. Sizing and phenotyping of cellular vesicles using Nanoparticle Tracking Analysis. Nanomedicine 2011; 7: 780-8.

32 Yuana Y, Oosterkamp TH, Bahatyrova S, Ashcroft B, Garcia Rodriguez P, Bertina RM, et al. Atomic force microscopy: a novel approach to the detection of nanosized blood microparticles. J Thromb Haemost 2010; 8: 315-23.

33 Ay C, Freyssinet JM, Sailer T, Vormittag R, Pabinger I. Circulating procoagulant microparticles in patients with venous thromboembolism. Thromb Res 2009; 123: 724-6.

34 Bal L, Ederhy S, Di Angelantonio E, Toti F, Zobairi F, Dufaitre G, et al. Factors influencing the level of circulating procoagulant microparticles in acute pulmonary embolism. Arch Cardiovasc Dis 2010; 103: 394403.

35 Bucciarelli P, Martinelli I, Artoni A, Passamonti SM, Previtali E, Merati G, et al. Circulating microparticles and risk of venous thromboembolism. Thromb Res 2012; 129: 591-7.

36 Campello E, Spiezia L, Radu CM, Bulato C, Castelli M, Gavasso S, et al. Endothelial, platelet, and tissue factor-bearing microparticles in cancer patients with and without venous thromboembolism. Thromb Res 2011; 127: 473-7.

37 Chirinos JA, Heresi GA, Velasquez H, Jy W, Jimenez JJ, Ahn E, et al. Elevation of endothelial microparticles, platelets, and leukocyte activation in patients with venous thromboembolism. J Am Coll Cardiol 2005; 45: 1467-71.

38 Ye R, Ye C, Huang Y, Liu L, Wang S. Circulating tissue factor positive microparticles in patients with acute recurrent deep venous thrombosis. Thromb Res 2012; 130: 253-8.

39 Mackman N, Tilley RE, Key NS. Role of the extrinsic pathway of blood coagulation in hemostasis and thrombosis. Arterioscler Thromb Vasc Biol 2007; 27: 1687-93.

40 Moore KL, Andreoli SP, Esmon NL, Esmon CT, Bang NU. Endotoxin enhances tissue factor and suppresses thrombomodulin expression of human vascular endothelium in vitro. J Clin Invest 1987; 79: 12430.

41 Owens AP 3rd, Mackman N. Microparticles in hemostasis and thrombosis. Circ Res 2011; 108: 1284-97.

42 Abid Hussein MN, Meesters EW, Osmanovic N, Romijn FP, Nieuwland $\mathrm{R}$, Sturk A. Antigenic characterization of endothelial cell-derived microparticles and their detection ex vivo. J Thromb Haemost 2003; 1: 2434-43.

43 Biró E, Sturk-Maquelin KN, Vogel GM, Meuleman DG, Smit MJ, Hack $\mathrm{CE}$, et al. Human cell-derived microparticles promote thrombus formation in vivo in a tissue factor-dependent manner. J Thromb Haemost 2003; 1: 2561-8.

44 Satta N, Toti F, Feugeas O, Bohbot A, Dachary-Prigent J, Eschwège $\mathrm{V}$, et al. Monocyte vesiculation is a possible mechanism for dissemination of membrane-associated procoagulant activities and adhesion molecules after stimulation by lipopolysaccharide. J Immunol 1994; 153: 3245-55.

45 Shet AS, Aras O, Gupta K, Hass MJ, Rausch DJ, Saba N, et al. Sickle blood contains tissue factor-positive microparticles derived from endothelial cells and monocytes. Blood 2003; 102: 2678-83.

46 Siddiqui FA, Desai H, Amirkhosravi A, Amaya M, Francis JL. The presence and release of tissue factor from human platelets. Platelets 2002; 13: 247-53.

47 Thomas GM, Panicot-Dubois L, Lacroix R, Dignat-George F, Lombardo D, Dubois C. Cancer cell-derived microparticles bearing P-selectin glycoprotein ligand 1 accelerate thrombus formation in vivo. J Exp Med 2009; 206: 1913-27.

48 von Bruhl ML, Stark K, Steinhart A, Chandraratne S, Konrad I, Lorenz M, et al. Monocytes, neutrophils, and platelets cooperate to initiate and propagate venous thrombosis in mice in vivo. J Exp Med 2012; 209: 819-35.

49 Hamilton KK, Hattori R, Esmon CT, Sims PJ. Complement proteins C5b-9 induce vesiculation of the endothelial plasma membrane and expose catalytic surface for assembly of the prothrombinase enzyme complex. J Biol Chem 1990; 265: 3809-14.

50 Berckmans RJ, Nieuwland R, Boing AN, Romijn FP, Hack CE, Sturk A. Cell-derived microparticles circulate in healthy humans and support low grade thrombin generation. Thromb Haemost 2001; 85: 639-46.

51 Horstman LL, Ahn YS. Platelet microparticles: a wide-angle perspective. Crit Rev Oncol Hematol 1999; 30: 111-42.

52 Sims PJ, Wiedmer T, Esmon CT, Weiss HJ, Shattil SJ. Assembly of the platelet prothrombinase complex is linked to vesiculation of the platelet plasma membrane. Studies in Scott syndrome: an isolated defect in platelet procoagulant activity. J Biol Chem 1989; 264: 17049-57.

53 Lentz BR. Exposure of platelet membrane phosphatidylserine regulates blood coagulation. Prog Lipid Res 2003; 42: 423-38.

54 Freyssinet JM, Toti F. Membrane microparticle determination: at least seeing what's being sized! J Thromb Haemost 2010; 8: 311-4.

55 Mause SF, Weber C. Microparticles: protagonists of a novel communication network for intercellular information exchange. Circ 
Res 2010; 107: $1047-57$.

56 Thery C, Ostrowski M, Segura E. Membrane vesicles as conveyors of immune responses. Nat Rev Immunol 2009; 9: 581-93.

57 Liu ML, Scalia R, Mehta JL, Williams KJ. Cholesterol-induced membrane microvesicles as novel carriers of damage-associated molecular patterns: mechanisms of formation, action, and detoxification. Arterioscler Thromb Vasc Biol 2012; 32: 2113-21.

58 Liu ML, Williams KJ. Microvesicles: potential markers and mediators of endothelial dysfunction. Curr Opin Endocrinol Diabetes Obes 2012; 19: 121-7.

59 Ruggeri ZM. The role of von Willebrand factor in thrombus formation. Thromb Res 2007; 120: S5-9.

60 Ley K, Laudanna C, Cybulsky MI, Nourshargh S. Getting to the site of inflammation: the leukocyte adhesion cascade updated. Nat Rev Immunol 2007; 7: 678-89.

61 Williams MR, Azcutia V, Newton G, Alcaide P, Luscinskas FW. Emerging mechanisms of neutrophil recruitment across endothelium. Trends Immunol 2011; 32: 461-9.

62 Musolino C, Alonci A, Allegra A, Spatari G, Bellomo G, Tringali O, et al. Increased levels of the soluble adhesion molecule E-selectin in patients with chronic myeloproliferative disorders and thromboembolic complications. Am J Hematol 1998; 57: 109-12.

63 Smith A, Quarmby JW, Collins M, Lockhart SM, Burnand KG. Changes in the levels of soluble adhesion molecules and coagulation factors in patients with deep vein thrombosis. Thromb Haemost 1999; 82: 1593-9.

64 Jy W, Jimenez JJ, Mauro LM, Horstman LL, Cheng P, Ahn ER, et al. Endothelial microparticles induce formation of platelet aggregates via a von Willebrand factor/ristocetin dependent pathway, rendering them resistant to dissociation. J Thromb Haemost 2005; 3: 1301-8.

65 Huber J, Vales A, Mitulovic G, Blumer M, Schmid R, Witztum JL, et al. Oxidized membrane vesicles and blebs from apoptotic cells contain biologically active oxidized phospholipids that induce monocyteendothelial interactions. Arterioscler Thromb Vasc Biol 2002; 22 : 101-7.

66 Patel KD, Zimmerman GA, Prescott SM, McIntyre TM. Novel leukocyte agonists are released by endothelial cells exposed to peroxide. J Biol Chem 1992; 267: 15168-75.

67 Falati S, Liu Q, Gross P, Merrill-Skoloff G, Chou J, Vandendries E, et al. Accumulation of tissue factor into developing thrombi in vivo is dependent upon microparticle P-selectin glycoprotein ligand 1 and platelet P-selectin. J Exp Med 2003; 197: 1585-98.

68 Furie B, Furie BC. Mechanisms of thrombus formation. N Engl J Med 2008; 359: 938-49.

69 Meier TR, Myers DD Jr, Wrobleski SK, Zajkowski PJ, Hawley AE, Bedard $\mathrm{PW}$, et al. Prophylactic P-selectin inhibition with PSI-421 promotes resolution of venous thrombosis without anticoagulation. Thromb Haemost 2008; 99: 343-51.

70 Mesri M, Altieri DC. Leukocyte microparticles stimulate endothelial cell cytokine release and tissue factor induction in a JNK1 signaling pathway. J Biol Chem 1999; 274: 23111-8.

71 Puddu P, Puddu GM, Cravero E, Muscari S, Muscari A. The involvement of circulating microparticles in inflammation, coagulation and cardiovascular diseases. Can J Cardiol 2012; 26: 140-5.

72 Barry OP, Pratico D, Lawson JA, FitzGerald GA. Transcellular activation of platelets and endothelial cells by bioactive lipids in platelet microparticles. J Clin Invest 1997; 99: 2118-27.

73 Freyssinet JM. Cellular microparticles: what are they bad or good for? J Thromb Haemost 2003; 1: 1655-62.
74 Jy W, Mao WW, Horstman L, Tao J, Ahn YS. Platelet microparticles bind, activate and aggregate neutrophils in vitro. Blood Cells Mol Dis 1995; 21: 217-31.

75 Key NS, Chantrathammachart P, Moody PW, Chang JY. Membrane microparticles in VTE and cancer. Thromb Res 2010; 125: S80-3.

76 Lima LG, Oliveira AS, Campos LC, Bonamino M, Chammas R, Werneck $C$, et al. Malignant transformation in melanocytes is associated with increased production of procoagulant microvesicles. Thromb Haemost 2011; 106: 712-23.

77 Manly DA, Wang J, Glover SL, Kasthuri R, Liebman HA, Key NS, et al. Increased microparticle tissue factor activity in cancer patients with Venous Thromboembolism. Thromb Res 2010; 125: 511-2.

78 Thaler J, Ay C, Weinstabl H, Dunkler D, Simanek R, Vormittag R, et al. Circulating procoagulant microparticles in cancer patients. Ann Hematol 2011; 90: 447-53.

79 Zwicker Jl, Liebman HA, Neuberg D, Lacroix R, Bauer KA, Furie BC, et al. Tumor-derived tissue factor-bearing microparticles are associated with venous thromboembolic events in malignancy. Clin Cancer Res 2009; 15: 6830-40.

80 Tesselaar ME, Romijn FP, van der Linden IK, Bertina RM, Osanto S. Microparticle-associated tissue factor activity in cancer patients with and without thrombosis. J Thromb Haemost 2009; 7: 1421-3.

81 Tallman MS, Lefebvre P, Baine RM, Shoji M, Cohen I, Green D, et al. Effects of all-trans retinoic acid or chemotherapy on the molecular regulation of systemic blood coagulation and fibrinolysis in patients with acute promyelocytic leukemia. J Thromb Haemost 2004; 2: 1341-50.

82 McEver RP, Cummings RD. Perspectives series: cell adhesion in vascular biology. Role of PSGL-1 binding to selectins in leukocyte recruitment. J Clin Invest 1997; 100: 485-91.

83 Chou J, Mackman N, Merrill-Skoloff G, Pedersen B, Furie BC, Furie B. Hematopoietic cell-derived microparticle tissue factor contributes to fibrin formation during thrombus propagation. Blood 2004; 104: 3190-7.

84 Khorana AA, Francis CW, Menzies KE, Wang JG, Hyrien O, Hathcock J, et al. Plasma tissue factor may be predictive of venous thromboembolism in pancreatic cancer. J Thromb Haemost 2008; 6: 1983-5.

85 Massberg S, GrahI L, von BruehI ML, Manukyan D, Pfeiler S, Goosmann C, et al. Reciprocal coupling of coagulation and innate immunity via neutrophil serine proteases. Nat Med 2010; 16: 887 96.

86 Myers DD Jr, Rectenwald JE, Bedard PW, Kaila N, Shaw GD, Schaub $\mathrm{RG}$, et al. Decreased venous thrombosis with an oral inhibitor of $\mathrm{P}$ selectin. J Vasc Surg 2005; 42: 329-36.

87 Palabrica T, Lobb R, Furie BC, Aronovitz M, Benjamin C, Hsu YM, et al. Leukocyte accumulation promoting fibrin deposition is mediated in vivo by P-selectin on adherent platelets. Nature 1992; 359: 848-51.

88 Martinez MC, Andriantsitohaina R. Microparticles in angiogenesis: therapeutic potential. Circ Res 2011; 109: 110-9.

89 Fleissner F, Goerzig Y, Haverich A, Thum T. Microvesicles as novel biomarkers and therapeutic targets in transplantation medicine. Am J Transplant 2012; 12: 289-97.

90 Tang K, Zhang Y, Zhang H, Xu P, Liu J, Ma J, et al. Delivery of chemotherapeutic drugs in tumour cell-derived microparticles. Nat Commun 2012; 3: 1282.

91 Vlassov AV, Magdaleno S, Setterquist R, Conrad R. Exosomes: current knowledge of their composition, biological functions, and diagnostic and therapeutic potentials. Biochim Biophys Acta 2012; 1820: 9408 . 